\title{
DAMPAK KEMAMPUAN DAN PENGALAMAN KERJA TERHADAP KINERJA KARYAWAN
}

\author{
Ahmad Sumitra $^{1}$, Deni Muhammad Danial ${ }^{2}$, Eryy Sunarya ${ }^{3}$ \\ Universitas Muhammadiyah Sukabumi ${ }^{1,2,3}$ \\ Email: Sumitra2019@gmail.com ${ }^{1}$
}

\begin{abstract}
ABSTRAK
Penelitian ini bertujuan untuk mengetahui pengaruh Kemampuan (Variabel X1) dan Pengalaman Kerja (Variabel X2) terhadap kinerja karyawan. Metode yang digunakan dalam penelitian ini yaitu menggunakan metode deskriptif dan metode asosiatif. Teknik pengumpulan data yang dilakukan peneliti dalam penelitian ini yaitu melalui observasi, wawancara angket, dokumentasi dan studi kepustakaan. Teknik analisa data dimulai dari penyusunan data, tabulasi data hingga tahap pengujian.Berdasarkan dari hasil perhitungan penelitian analisis Regresi linier berganda. Nilai koefisien determinasi $\left(\mathrm{R}^{2}\right)$ dapat diperoleh hasil dari varaiabel kemampuan (X1) dan pengalaman kerja (X2) mempengaruhi sebesar 89,8\% (0,898) terhadap kinerja karyawan (Y), sisanya 10,2\% dipengaruhi oleh faktor-faktor lain diluar penelitian ini. Simpulan, kemampuan dan pengalaman kerja berdampak terhadap kinerja karyawan
\end{abstract}

Kata Kunci: Kemampuan, Pengalaman Kerja, Kinerja Karyawan.

\section{ABSTRACT}

This study aims to determine the effect of Ability (Variable X1) and Work Experience (Variable X2) on employee performance. The method used in this study is using descriptive methods and associative methods. Data collection techniques conducted by researchers in this study are through observation, questionnaire interviews, documentation and literature study. Data analysis techniques start from the compilation of data, tabulation of data up to the testing phase. Based on the results of the calculation of the study of multiple linear regression analysis. The coefficient of determination (R2) can be obtained from the capability variable (X1) and work experience (X2) affects $89.8 \%$ (0.898) on employee performance $(Y)$, the remaining $10.2 \%$ is influenced by other factors outside the research this. Conclusions, abilities and work experience have an impact on employee performance

Keywords: Ability, Work Experience, Employee Performance.

\section{PENDAHULUAN}

Pada jaman sekarang persaingan usaha berkembang lebih pesat seiring menjamurnya perusahaan. Banyaknya persaingan dalam perusahaan manufaktur atau lainnya. Dengan pengaturan manajemen sumber daya manusia profersional, di harapkan pegawai bekerja secara produktif. Pentingnya sumber daya manusia, karena dengan 
adanya sumber daya manusia bisa mengelola dan mengatur sehingga dapat berjalannya suatu tujuan perusahaan.

Perusahaan sangat membutuhkan sumber daya manusia (tenaga kerja) yang efisiensi dan produktif. Tenaga kerja seperti inilah yang di harapkan akan mampu bersaing dengan tenaga kerja yang lain guna mencapai target produksi sendiri bagi perusahaan. Keunggulan tersebut dapat tercapai bila semua individu dari karyawan dapat berperan aktif dengan tingkat kemampuan yang baik dalam kinerja. Pengelola pegawai secara profesional ini harus di mulai sejak prekrutan pegawai sesuai dengan kemampuan, penataran dan perkembangan karir karyawan. Dalam suatu perusahaan, permasalahan dalam kinerja adalah suatu hal yang umum, tidaklah wajar banyaknya karyawan yang mempunyai kemampuan tinggi tetapi tidak mempunyai keingian untuk berprestasi dalam kerja.

Kemajuan-kemajuan di berbagai bidang, antara lain di bidang teknologi menyebabkan berubahnya cara dalam bekerja dan usaha mencapai tujuan tertentu. Terbatasnya sumber-sumber kebutuhan manusia yang di butuhkan dalam proses pencapaian usaha, menentukan dilaksanakannya cara kerja yang efektif dan efisiensi. Hal ini diperlukannya manajemen berdasarkan ilmu pengetahuan yang lebih maju, untuk mengatasi masalah-masalah yang di hadapi di dalam usaha pencapaian tujuan dengan hasil optimal. Untuk tercapainya tingkat keberhasilan suatu tujuan perusahan yaitu dengan adanya kinerja karyawan.

Kinerja karyawan sebuah perilaku yang nyata dari hasil setiap individu dalam melaksanakan perannya dalam pekerjaan di perusahan tersebut. Untuk itu setiap karyawan harus melaksanakan tugasnya dengan tanggung jawabnya supaya target produksi yang diinginkan perusahaan tercapai. Setiap perusahaan menginginkan tercapainya target, dengan itu karyawan harus mengerjakan tugasnya dengan tepat waktu dan tidak adanya keterlambatan menegrjakan tugas supaya tidak adanya kelalaian dalam bekerja sehingga hasil yang diingikan perusahaan tercapai. Maka untuk mendapat kinerja yang baik.

Organisasi harus memberikan sarana dan prasarana bagi karyawan supaya hasil yang diinginkan memuaskan sehingga karyawan tidak malas dalam bekerja. Sarana yang di perlukan menilai seberapa baiknya kinerja kemampuan, pengalaman dan tanggung jawab dalam tugasnya. Hasil dari penilaian di evaluasi dan di tolak ukur 
seberapa besar karyawan bertanggung jawab melaksanakan tugasnya. Dengan adanya penilaian kinerja ini agar bisa memotivasi setiap kinerja yang di laksanakan karyawan untuk mencapai target tuntutan perusahaan. Istilah kinerja berasal dari kata Job Performance atau Actual Perfomance (prestasi atau prestasi sesungguhnya yang di capai oleh seseorang). Pengertian kinerja (prestasi kerja) adalah hasil kerja secara kualitas dan kuantitas yang dicapai oleh seorang pegawai dalam melaksanakan tugasnya sesuai dengan tanggung jawab yang diberikan kedepannya (Mangkunegara 2012). Untuk mengasilkan kinerja yang baik, maka untuk itu kemampuan dalam pekerjaan harus ditingkatkan.

Dalam sebuah organisasi dan perusahaan manusia mempunyai karakteristik yang berbeda-beda setiap individunya. Namun dalam setiap karakteristik yang di miliki masing-masing karyawan dengan karakteristik, sikap, dan kepribadian yang berbeda. Dengan demikian terlihat dalam segi kemampuan karyawan, karena karyawan mempunyai kekuatan dan kelemahan dalam bekerja. Kemampuan-kemampuan yang dimilkinya mampu memberikan pertimbangan dalam melakukan tugas dan tanggung jawabnya. Hal ini kemampuan berkaitan dengan kesanggupan karyawan dalam melaksanakan tugas guna mencapai hasil melalui karakteristik, proses, atau pelaksanaan yang bisa diukur dari pencapaian suatu pekerjaan tertentu.

Adapun Kemampuan-kemampuan yang dapat di bedakan dengan kemampuan fisik dan mental, kemampuan fisik ini mengerjakan suatu tugas pekerjaan yang menguras stamina dan kemampuan mental mengerjakan tugas dengan caranya sendiri. Maka dari itu kemampuan kerja yang harus di perhatikan, karena kurangnya kemampuan dalam bekerja mampu merugikan suatu perusahaan dan sebaliknya karyawan yang mempunyai kemampuan dalam bekerja akan tercapainya keinginan perusahan. Dengan demikian untuk mengetahui kemampuan karyawan dalam melaksanakan tugas ataupun tanggung jawabnya, perlunya pengalaman kerja agar bisa meningkatkan kemampuan karyawan, sehingga karyawan akan lebih kuat untuk mampu melaksankan tuntutan kerja yang telah di tentukan organisasi atau perusahan tertentu.

Pengalaman kerja juga salah satu hal yang sangat penting bagi setiap individu untuk melaksanakan tugas dan tanggung jawabnya. Diukur dengan seberapa lama waktu ataupun masa kerja yang pernah di alami pekerja tersebut. Oleh karena itu seorang 
karyawan yang mengalami pengalaman kerja yang lebih lama, akan mampu mengerti dengan adanya masalah yang muncul dalam pekerjaan. Selain itu karyawan mampu lebih cepat memahami dan mengerjakan apa yang harus di kerjakan sehingga tidak harus beradaptasi lagi dengan tugas yang akan dilaksanakan, karena sudah memiliki pengalaman. Hal ini akan membuat orang tersebut bekerja lebih efektif dan efisien, sehingga perusahaan lebih mudah mencapai tujuan, didukung dengan adanya karyawan yang sudah berpengalaman dalam bidang masing-masing.

Pengalamam kerja bukan hanya menyangkut tentang seberapa lamanya waktu yang dialami, tetapi bisa juga menghitung jenis pekerjaan yang sering dihadapi atau yang pernah dihadapi. Berapa banyaknya pekerjaan, maka lebih banyak lagi pengetahuan ataupun ke ahlian yang dimiliki ataupun dengan sebaliknya. Dengan adanya pengalaman kerja mampu memberikan hal penting bagi perusahaan untuk mencapai suatu tujuan yang diingingkan, tetapi banyaknya suatu perusahaan yang tidak mampu mencapai suatu tujuan karena tidak adanya pelatihan ataupun pengalaman kerja yang tidak dimiliki oleh karyawan, sehingga menghambat tercapainya tujuan perusahaan.

PT. Fahmi Cipta Abadi Sukabumi yang merupakan sebuah perusahaan lokal (Home Industry) yang bergerak dibidang automotive dan electrical componentmanufacturyng. PT. Fahmi Cipta Abadi Sukabumi didirikan tepatnya pada bulan Januari 1995 dan mulai berjalan pada tahun 2000. Dalam pelaksanaan produksinya masih terdapat karyawan yang belum mengerti dan menguasai cara menggunakan peralatan dalam pekerjaan dan kerjasama antar karyawan masih kurang sehingga menghambat proses pekerjaan.

Berdasarkan dari target kerja karyawan adanya permasalahan dalam Kinerja Karyawan yamg dilihat dari tidak tercapainya target dalam kuru waktu 3 bulan terhitung dari bulan Agustus sebesar 40,8\%, September sebesar 7,50\%, dan bulan Oktober sebesar 32,5\%. Hal tersebut di duga disebabkan oleh kemampuan dan pengalaman kerja yang di miliki karyawan dalam bekerja sehingga menghambat pencapaian target yang telah ditentukan perusahaan. 


\section{KAJIAN TEORI}

\section{Sumber Daya Manusia}

Manajemen adalah proses pendayagunaan seluruh daya yang dimiliki organisasi untuk mencapai tujuan yang telah ditetapkan. Proses dimaksud melibatkan organisasi, arahan, koordinasi, dan evaluasi orang-orang guna mencapai tujuan yang ditetapkan tersebut Simamora (2001). Manajemen sumber daya manusia menurut Hasibuan (2012), menyatakan bahwa manajemen sumber daya manusia merupakan suatu bidang manajemen yang khusus mempelajari hubungan dan peranan tenaga kerja agar efektif dan efisien, dalam terwujudnya tujuan perusahaan

Berdasarkan pengertian menurut para ahli diatas dapat disimpulkan bahwa terdapat perbedaan antara keempat definisi diatas, ada yang mengemukakan bahwa manajemen sumber daya manusia itu adalah tujuan tertentu dalam organisasi, adapun yang mengemukakan manajemen yang khusus mempelajari hubungan tenaga kerja, namun beda dengan pernyataan berikutnya bahwa manajemen sumber daya manusia merupakan serangkaian perencanaan, pengorganisasian untuk mencapai tujuan individu, lain halnya dengan pendapat satu lagi bahwa manajemen sumber daya manusia adalah pemanfaatan sumber daya manusia dengan sebaik mungkin.

\section{Kemampuan}

Menurut Anwar Prabu Mangkunegara (2012) menyatakan manajemen sumber daya manusia merupakan suatu perencanaan, pengorganisasian, pengkoordinasian, pelaksanaan dan pengawasan terhadap pengadaan, pengembangan, pemberian balas jasa, pengintegrasian, pemeliharaan, dan pemisa tenaga kerja dalam rangka mencapai tujuan organisasi. Teori Kemaampuan menurut Thoha (2011), kemampuan kerja merupakan salah satu unsur dalam kematangan berkaitan dengan pengetahuan atau keterampilan yang dapat diperoleh dari pendidikan, pelatihan dan suatu pengalaman. Menurut Syafarudin dalam Robbins (2008), terdapat tiga jenis kemampuan SDM dalam dimensi kualitas yang perlu dikaji, yaitu: 1. Conceptual Skill (Kemampuan Konseptual) Keahlian konseptual menyangkut kemampuan individu dalam organisasi dalam berbagai fungsi manajerial seperti pengambilan keputusan, penyelesaian konflik dan problem yang kompleks, penyusunan strategi dan kebijakan. Kemampuan ini memerlukan dukungan pengetahuan yang harus selalu diperbaharui,2. Human Skill 
(Kemampuan Bersifat Manusiawi) Pada diri individu pada level jabatan apapun, harus memiliki kemampuan ini yang terlihat pada kemampuan bekerja sama, interrelionship, komunikasi dalam kelompok, kemampuan-kemampuan seperti itu, harus dimiliki oleh semua manajer pada setiap tingkat manajemen, 3. Technical Skill (Kemampuan Teknis) Keahlian yang bersifat teknikal adalah kemampuan individu yang lebih bersifat keahlian khusus teknis operasional seperti mengoperasikan alat-alat dan kegiatan-kegiatan yang bersifat administratif lainnya. Kemampuan dan keahlian itu bagi peningkatan efektivitas organisasi diberbagai level harus selalu ditingkatkan guna mencapai tujuan yang diharapkan sejalan dengan perubahan yang dihadapi.

\section{Pengalaman Kerja}

Teori Pengalaman menurut Gibson (2018), berpendapat orang yang mempunyai pengalaman akan selalu lebih pandai dalam menyikapi dari segala hal daripada mereka yang sama sekali tidak memiliki pengalaman.Menurut Foster dalam Aristarini (2014) mengemukakan beberapa indikator pengalaman kerja antara lain, yaitu: 1. Lama waktu / masa kerjaUkuran tentang lama waktu atau masa kerja yang telah ditempuh seseorang dapat memahami tugas-tugas suatu pekerjaan dan telah melaksanakan dengan baik. 2. Tingkat pengetahuan dan keterampilan yang dimiliki pengetahuan merujuk pada konsep, prinsip,prosedur,kebijakan atau informasi lain yang dibutuhkan oleh karyawan. Pengetahuan juga mencakup kemampuan untuk memahami dan menerapkan informasi pada tanggung jawab pekerjaan. 3.Penguasaan terhadap pekerjaan dan peralatan tingkat penguasaan seseorang dalam pelaksanaan aspek-aspek teknik peralatan dan teknik pekerjaan.

\section{Kinerja Karyawan}

Teori Kinerja Karyawan menurut Mangkuprawira (2007) mengatakan bahwa kinerja adalah hasil dari proses pekerjaan tertentu secara terencana pada waktu dan tempat dari karyawan serta organisasi bersangkutan, yang dijadikan dimensi yaitu menurut Bangun (2012) kinerja karyawan dapat dinilai dari:

1. Jumlah Pekerjaan. Dimensi ini menunjukan jumlah pekerjaan yang dihasilkan individu atau kelompok sebagai standar persyaratan yang menjadi standar pekerjaan. Setiap pekerjaan memiliki persyaratan yang berbeda sehingga menurut karyawan 
harus memenuhi persyaratan tersebut baik pengetahuan, keterampilan, maupun kemampuan yang sesuai.

2. Kualitas Pekerjaan. Setiap karyawan dalam perusahaan harus memiliki persyaratan tertentu agar dapat menghasilkan pekerjaan sesuai dengan kualitas tertentu yang harus disesuaikan oleh karyawan untuk dapat menegerjakannya sesuai dengan ketentuan.

3. Ketepatan Waktu. Karyawan mampu menyelesaikan pekerjaan tepat pada waktunya.

4. Kehadiran. Suatu jenis pekerjaan tertentu menuntut kehadiran karyawan dalam mengerjakannya sesuai waktu yang ditentukan. Ada tipe pekerjaan yang menuntut kehadiran karyawan selama delapan jam sehari untuk lima hari kerja dalam seminggu. Kinerja karyawan ditentukan oleh tingkat kehadiran karyawan dalam mengerjakannya

5. Kemampuan Kerjasama. Tidak semua pekerjaan dapat diselesaikan oleh satu orang karyawan saja. Untuk jenis pekerjaan tertentu mungkin harus dikerjakan oleh dua orang karyawan atau lebih, sehingga membutuhkan kerjasama antar karyawan sangat dibutuhkan. Kinerja karyawan dapat dinilai dari kemampuannya bekerjasama dengan rekan sepekerjaan yang lainnya.

Adapun hubungan kemampuan terhadap kinerja karyawan menurut Robbins (2008), mendefinisikan "kemampuan (ability) adalah suatu kapasitas seorang individu untuk mengerjakan berbagai tugas dalam suatu pekerjaan. Individu yang tingkat kemampuannya tinggi cenderung akan menyelesaikan tugas pekerjaan dengan baik, cepat dan tepat..

\section{METODE PENELITIAN}

Sugiyono (2016) Menjelaskan bahwa Metode penelitian kuantitatif dapat di artikan sebagai metode penelitian yang berlandaskan pada filsafat positivisme, digunakan untuk meneliti pada populasi atau sampel tertentu yang dilakukan dengan cara random dan pengumpulan datanya menggunakan instrumen penelitian, analisa datanya bersifat statistik guna menguji hipotesis yang telah ditetapkan.. Menurut Sugiyono (2016), menjelaskan bahwa "metode penelitian deskriptif adalah penelitian yang dilakukan untuk mengetahui nilai variabel mandiri, baik hanya pada suatu variabel atau lebih tanpa membuat perbandingan". 
Selanjutnya menurut Sugiyono (2016), menjelaskan bahwa "penelitian asosiatif merupakan penelitian yang bertujuan untuk mengetahui hubungan antara. Penelitian ini menggunakan pendekatan manajemen sumber daya manusia khususnya pada dampak kemampuan dan pengalaman kerja terhadap kinerja karyawan. Dalam penelitian ini terdapat 3 variabel yang akan di gunakan, yang akan di jadikan penelitian yaitu: kemampuan (variabel X1), pengalaman kerja (variabel X2),dankinerjakaryawan (variabel Y).

Dimana yang di jadikan variabel terikat (devendent variabel) adalah kinerja karyawan dan yang menjadi variabel bebas (independent variabel) adalah kemampuan dan pengalaman kerja.Teknik pengumpulan data menggunakan observasi, wawancara, angket, dokumentasi dan studi kepustakaan. Teknik analisa data menggunakan koefisien korelasi ganda untuk mengukur hubungan antar variabel, koefisien determinasi untuk mengukur pengaruh variabel kemampuan dan variabelpengalaman kerja terhadap kinerja karyawan, analisis regresi berganda untuk mengukur konsistensi nilai variabel terikat dan uji $\mathrm{F}$ untuk menguji hipotesis. Adapun populasi dalam penelitian ini adalah Karyawan PT. Fahmi Cipta Abadi Sukabumi. Teknik pengambilan sampel yang digunakan oleh peneliti adalah teknik sampling jenuhsemua anggota populasi digunakan sebagai sampel. Penelitian ini menggunakan uji validitas dengan rumus product moment dan uji reliabilitas dengan rumus cronbach's alpha. Angket yang disebar menggunakan skala Likert dengan pernyataan positif.

\section{HASIL PENELITIAN}

\section{Hasil analisis Regresi Linier Berganda}

Regresi linier berganda yaitu untuk meneliti pengaruh beberapa variabel yang berkorelasi dengan variabel yang diuji. Hasil dari regresi linier berganda dapat dilihat pada tabel 1 yaitu: 
Tabel 1

Hasil Uji Regresi LinierBerganda

\begin{tabular}{|c|c|c|c|c|c|c|}
\hline \multicolumn{7}{|c|}{ Coefficients $^{\mathrm{a}}$} \\
\hline \multicolumn{2}{|c|}{ Model } & \multicolumn{2}{|c|}{$\begin{array}{c}\text { Unstandardized } \\
\text { Coefficients }\end{array}$} & \multirow{2}{*}{$\begin{array}{c}\begin{array}{c}\text { Standardized } \\
\text { Coefficients }\end{array} \\
\text { Beta }\end{array}$} & \multirow[t]{2}{*}{$\mathrm{T}$} & \multirow[t]{2}{*}{ Sig. } \\
\hline & & $\mathrm{B}$ & $\begin{array}{l}\text { Std. } \\
\text { Error }\end{array}$ & & & \\
\hline \multirow[t]{3}{*}{1} & $\begin{array}{l}\text { Cons } \\
\operatorname{tant})\end{array}$ & 1,072 & 1,424 & & ,753 &, 457 \\
\hline & $\mathrm{x} 1$ & ,319 & 115 & 400 & 2,770 & ,010 \\
\hline & $\mathrm{x} 2$ &, 575 & ,146 & 569 & 3,939 &, 000 \\
\hline
\end{tabular}

a. Dependent Variable: $\mathrm{y}$

Sumber: data primer (kuisioner) 2019

Tabel 1 di atas menjelaskan Dari output uji regresi linear berganda diatas, maka dapat diperoleh persamaan bagaimana dijelaskan berikut ini:

$\mathrm{Y}=1,072+0,319 \mathrm{X} 1+0,575 \mathrm{X} 2$

\section{Hasil Koefisien Determinasi}

Tabel 2

\begin{tabular}{ccccc}
\hline $\begin{array}{l}\text { Mo } \\
\text { del }\end{array}$ & R & $\begin{array}{c}\mathrm{R} \\
\text { Square }\end{array}$ & $\begin{array}{c}\text { Adjusted R } \\
\text { Square }\end{array}$ & $\begin{array}{c}\text { Std. Error of } \\
\text { the Estimate }\end{array}$ \\
\hline 1 & $\begin{array}{r}95 \\
1^{\text {a }}\end{array}$ &, 904 &, 898 &, 88340 \\
\hline
\end{tabular}

a. Predictors: (Constant), $\mathrm{x} 2, \mathrm{x} 1$

Sumber: Data primer (Kuisioner) 2019

Hasil tabel 2 diatas model summary besarnya adjusted $\mathrm{R}^{2}$ yaitu 0,898 ; hal ini jadi $89,8 \%$ variasi kinerja karyawan dapat dijelaskan oleh variasi dari dua variabel independen Budaya kaizen dan Reward sedangkan sisanya 10,2\% (100\%$89,8 \%=10,2 \%$ ) dari faktor yang tidak diteliti. 


\section{Koefisien Korelasi Berganda}

Tabel 3

Hasil Koefisien Korelasi Berganda

Model Summary

\begin{tabular}{|l|r|r|r|r|}
\hline $\begin{array}{l}\text { Mod } \\
\text { el }\end{array}$ & R & R Square & \multicolumn{1}{|c|}{$\begin{array}{c}\text { Adjusted R } \\
\text { Square }\end{array}$} & $\begin{array}{c}\text { Std. Error of } \\
\text { the Estimate }\end{array}$ \\
\hline 1 &, $951^{\mathrm{a}}$ &, 904 &, 898 &, 88340 \\
\hline
\end{tabular}

a. Predictors: (Constant), x2, x1

Sumber: data primer (Kuisioner) 2019

Berdasarkan tabel 3 diatas diperoleh angka $\mathrm{R}$ sebesar 0,951 berada pada kategori sangat tinggi Hal ini menuju bahwa dari variabel kemampuan (X1) dan pengalaman kerja (X2) memepengaruhi sebesar 89,8\% (0,898) terhadap kinerja karyawan (Y). sisanya 10,2\% dipengaruhi oleh fakto-faktor lain diluar penelitian ini. Maka hal ini dikarenakan pentingnya kemampuan dan pengalaman kerja guna sangat penting dalam meningktakan kinerja karyawan. Dengan itu dapat di ketahui bahwa kemampuan (X1) dan pengalaman kerja (X2) adalah salah satu faktor membentuk kinerja karyawan (Y) pada PT. Fahmi Cipta Abadi Sukabumi secara simultan.

\section{Uji Signifikan secara Simultan (Uji F)}

Tabel 4

Hasil Uji F

\begin{tabular}{|c|c|c|c|c|c|c|}
\hline \multicolumn{7}{|c|}{ ANOVA $^{a}$} \\
\hline \multicolumn{2}{|c|}{ Model } & Sum of & Df & Mean & $\mathrm{F}$ & Sig. \\
\hline \multirow[t]{3}{*}{1} & $\begin{array}{l}\text { Regress } \\
\text { ion }\end{array}$ & 220,467 & 2 & 110,233 & $\begin{array}{r}141,2 \\
52\end{array}$ &, $000^{\mathrm{b}}$ \\
\hline & $\begin{array}{l}\text { Residu } \\
\text { al }\end{array}$ & 23,412 & 30 & ,780 & & \\
\hline & Total & 243,879 & 32 & & & \\
\hline & $\begin{array}{l}\text { ependen } \\
\text { edictors } \\
\text { ber: } d a t\end{array}$ & $\begin{array}{l}\text { ariable: y } \\
\text { Constant), } \\
\text { rimer ( } K u\end{array}$ & & & & \\
\hline
\end{tabular}

Tabel 4 menjelaskan Uji F Variabel X1( Kemampuan), X2 (Pengalaman Kerja) dan Y (Kinerja Karyawan) yaitu sebesar 141,252, dapat diperoleh dari nilai 
signipikan 0,000 <0,05; nilai $\mathrm{F}_{\text {hitung }} 141,252>\mathrm{F}_{\text {tabel }} \ldots$ artinya bahwa kemampuan dan pengalaman kerja secara simultan berpengaruh terhadap kinerja karyawan.

\section{PEMBAHASAN}

Dapat diketahui dari uraian diatas bahwa kemampuan dan pengalaman kerja berpengaruh secara signifikan terhadap kinerja karyawan di PT. Fahmi Cipta Abadi Sukabumi. Dapat dilihat dari hasil jawaban setiap responden yang meiliki kemampuan dan pengalaman kerja

\section{Hasil Analisi Regresi Bersama-sama}

Berdasarkan dari hasil perhitungan penelitian analisis Regresi linier berganda. Nilai Koefisien Determinasi $\left(\mathrm{R}^{2}\right)$ dapat diperoleh hasil dari varaiabel kemampuan (X1) dan pengalaman kerja (X2) mempengaruhi sebesar 89,8\% (0,898) terhadap kinerja karyawan (Y), sisanya 10,2\% dipengaruhi oleh faktor-faktor lain diluar penelitian ini. Maka hal ini dikarenakan pentingnya kemampuan dan pengalaman kerja guna sangat penting dalam meningktakan kinerja karyawan. Dengan itu dapat di ketahui bahwa kemampuan (X1) dan pengalaman kerja (X2) adalah salah satu faktor membentuk kinerja karyawan (Y) pada PT. Fahmi Cipta Abadi Sukabumi secara simultan.

\section{SIMPULAN}

Berdasarkan hasil penelitian, pembahasan dan teknik data yang peneliti lakukan mengenai kemampuan dan pengalaman kerja terhadap kinerja karyawan pada PT. Fahmi Cipta Abadi Sukabumi, maka peneliti dapat mengambil kesimpulan sebagai berikut: 1) kemampuan kerja yang dimiliki karyawan dikatakan sedang dan dapat diatasi. Hal ini dapat dilihat dari dimensi kemampuan kerja yang direspon oleh karyawan bahwa kemampuan yang dimiliki karyawan masih berada di kategori sedang, namun ada beberapa dimensi yang masih perlu diperhatikan dan menjadi bahan evaluasi untuk perusahaan; 2) pengalaman kerja yang dimiliki karyawan dikatakan sedang. Hal ini dapat dilihat dari dimensi pengalaman kerja yang direspon oleh karyawan bahwa pengalaman kerja yang dimiliki setiap masing-masing karyawan harus diperhatikan; 3) kinerja karyawan dikatakan rendah. Hal ini dapat diartikan bahwa kinerja karyawan kurang baik dapat dilihat dari dimensi kinerja karyawan yang direspon oleh karyawan. 
Maka dari ini harus sangat diperhatikan dan segera ditangani; 4) kemampuan dan pengalaman kerja terhadap kinerja karyawan memiliki pengaruh signifikan, hal tersebut dapat disimpulkan setelah pengujian hipotesis, dan hal-hal lain yang mempengaruhi kinerja karyawan yang dipengaruhi oleh faktor-faktor lain yang tidak diketahui dalam penelitian ini. Kemampuan dan pengalaman kerja yang terjadi pada karyawan bersifat positif. Maka dari itu dapat diartikan bahwa kemampuan dan pengalaman kerja yang terjadi pada setiap individu karyawan tidak mempengaruhi kinerjanya.

\section{DAFTAR PUSTAKA}

Aristarini L., Kirya I. K., \& Yulianthini N. N (2014). Pengaruh Pengalaman Kerja, Kompetensi social dan Motivasi Kerja Terhadap Kinerja Karyawan. Jurnal eBisma Manjaemen. 2 (1), 1-10

Bangun, W. (2012). Manajemen Sumber Daya Manusia. Bandung : erlangga.

Gibson dalam Octavianus (2018). Pengarah Pengalaman Kerja terhadap Kinerja Karyawan PT. Telom Indonesia Cabang Manado. Jurnal EMBA, 6(3), 1758 1767.

Hasibuan, M. S. P. H. (2012). Manajmen Sumber Daya Manusia. Jakarta: PT. Bumi Aksara.

Mangkuprawira, TB S. (2007). Bisnis Manajemen dan Sumber Daya Manusia. Cetakan Kedua. Bogor: IPB Press

Mangkunegara, A. P. (2012). Evaluasi Kinerja SDM. Bandung: PT. Refika Aditama.

P.Robbin, Stephen. (2008). Perilaku Organisasi, Jakarta: PT.Indeks Kelompok Gramedia.

Simamora, Herny. (2001). Manajemen Sumber Daya Manusia. Yogyakarta: Bagian Penerbit STIE YKPN.

Sugiyono. (2016). Metode Penelitian Kombinasi. Bandung: Alfabeta.

Thoha, M. (2011). Perilaku Organisasi Konsep Dasar dan Aplikasinya. Jakarta: 